\title{
Latin America and the World Recession
}

\section{AREA: 1 TYPE: Theory}

AUTHOR

Alvaro VargasLLosa1

Senior Fellow at the Independent Institute and the editor of "Lessons from the Poor." AVLlosa@ independent.org

1. Corresponding Author:

The INDEPENDENT INSTITUTE; 100 Swan Way, Oakland, CA 94621-1428, USA

\section{América Latina y el recesión mundial} A América Latina e a Recessão Mundial

In this essay the author evaluates the impact the world recession has on Latin America. The region has lost the equivalent of $60 \%$ of its GDP. The sustained growth of recent years might disappear. Not all countries are prepared in the same way and a comparison with China and India is very relevant. Many figures are provided to illustrate the current situation and potential impact for the different countries in the region. In addition, the role different governments (categorized as vegetarian and carnivorous) will have in each situation is very relevant for the analysis. It concludes with a list of specific recommendations to be competitive, the only solution to prosper in a sustainable manner.

En este ensayo, el autor calcula el impacto de la recesión global en América Latina. La región ha perdido el equivalente al 60\% de su PIB. El crecimiento sostenido de los últimos años podría desaparecer. No todos los países están preparados del mismo modo y la comparación con China o la India resulta muy relevante. Se manejan multitud de cifras para ilustrar la situación actual y el impacto potencial en los distintos países de la región. Además, el papel que juegan los distintos gobiernos (divididos en vegetarianos o carnivoros) en cada caso es muy importante para el análisis. Concluye con una lista de recomendaciones concretas para la competitividad: es la única solución para poder prosperar de forma sostenible.

Neste artigo, o autor avalia o impacto da recessão mundial na América Latina. A região perdeu já o equivalente a $60 \%$ do seu PIB. O crescimento sustentado dos últimos anos poderá desaparecer. Nem todos os países estão preparados da mesma forma e uma comparação com a Índia e a China é muito importante. São fornecidos muitos dados numéricos, para ilustrar a actual situação e o potencial impacto da crise nos diversos países da região. Além disso, o papel que os diferentes governos (categorizados como vegetarianos e carnívoros) terão em cada situação é muito importante para a análise. Termina com uma lista das recomendações específicas para que os países sejam competitivos, única solução para poderem prosperar de uma forma sustentável.
DOI

$10.3232 /$

GCG.2009.

V3.N1.01 


\section{Latin America and the World Recession}

Three analysts were recently invited to the U.S. State Department to share some thoughts with the diplomats who serve in the Western Hemisphere. Surprisingly, all of us were mostly in agreement on the impact the current economic crisis will have on the region. Despite the warnings, Latin Americans were largely unaware of the implications of the U.S. financial meltdown and the recession until only a few weeks ago. They believed that the times when the U.S. sneezed and the region would catch a cold were gone. Brazilian President Lula da Silva even said, "Ask Bush about the crisis, because it's his, not mine" (Kraul 2008).

What an illusion. A lot of what has helped Latin America's economies in recent yearsaccess to capital markets, foreign investments, remittances from emigrants, the price of natural resources-depends on the health of the global marketplace. Any time the U.S. stock markets lose almost $\$ 7$ trillion in a year -twice Latin America's gross domestic product, the ripple effects will be felt south of the Rio Grande (Merle 2009).

Now the crisis has hit home. Claudio Loser of the Inter-American Dialogue has calculated that total losses for the region already amount to the equivalent of 60 percent of its GDP (Loser 2008).

The Brazilian stock index lost 41 percent of its value in the last half year and the real lost nearly 25 percent of its value against the dollar in 2008 (Alves 2008). Many of Brazil's companies, like Mexico's, had invested in credit-related instruments - the ones that sparked off the financial mess - to hedge against currency movements; once they began to lose money they tried to secure dollars, causing the devaluation of the currency. Economic output is back at pre-2006 levels, which were not great. No one thinks that the Brazilian government's stimulus package-amounting to the equivalent of 1 percent of the nation's GDP - will undo this damage anytime soon.

Mexico, whose economy is intertwined with that of the U.S., is suffering, as is Central America, also heavily dependent on the U.S.. Mexico's economy will probably contract this year.

Countries that are dependent on commodities are being severely affected. Nations such as Venezuela, Argentina, and Ecuador, not only heavily reliant on commodities but also unable to issue debt to raise money, are already responding to the adverse conditions with nationalizations and controls. The nationalization of Argentina's private pension system - which caused capital to fly to Uruguay - is a case in point.

Other nations whose exports have diversified somewhat, such as Peru, or put aside some rainy day money, such as Chile, are being less hurt by the current environment or at least have more flexibility to respond. They have announced stimulus packages that represent more than 2 percent of their respective GDPs.

According to most estimates, the average GDP for the region will drop 1.4 percent in 2009 in the best-case scenario (IMF 2009). To make matters worse in these times of

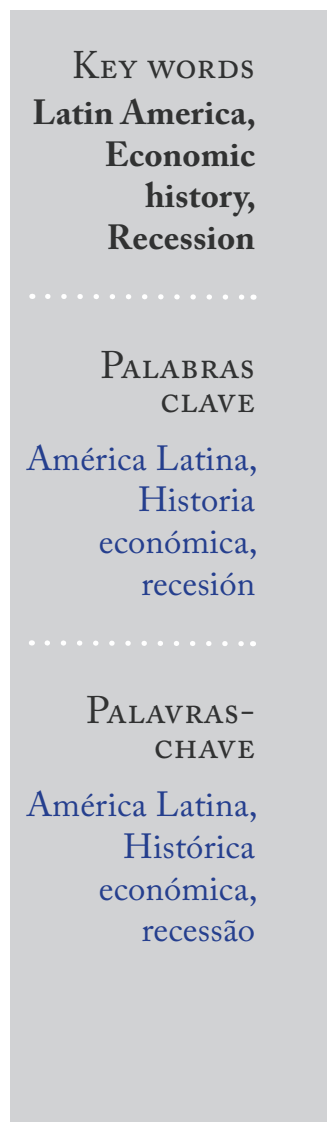

KEY WORDs

America,

history,

Recession

Palabras

CLAVE

Latina,

.

recesión

PALAVRASCHAVE

a Latina

Histórica

conómica, recessão

JEL Codes

F500; 0540;

0400 
restricted access to finance, the region will need more than $\$ 250$ billion to pay off maturing debt and support budgets (about a quarter of Brazil's public debt falls due this year). If the crisis were only in the United States, the expanded relations with China and other emerging economies might help. But China itself is being hit by the crisis, and for all the talk about China's role in Latin America's economy, the commercial exchange between the two is only a fifth of the commercial exchange between the U.S. and Latin America (which is more than $\$ 500$ billion) and Sino-Latin American commerce only represents between 5 and 6 percent of China's or Latin America's total trade (Ratliff 2008). China's imports fell by more than 20 percent in December of 2008, a sign that Latin America's commodity exports to that country are also going to be hit for the foreseeable future.

That might well change one day. By 2010 , 15 trade agreements will link 5 Latin American economies with 11 Asian economies, and 21 member nations of APEC have started to explore a Free Trade Area of the $\mathrm{Pa}$ cific that would include Mexico, Peru, Chile and perhaps Colombia. However, that is still a very preliminary exploration. For the moment, and given the circumstances, trade with Asia and Asian investment and capital markets are not enough to offset the current troubles.

There is a political upside, perhaps, to this state of affairs. The government in Caracas will find it tough to fund its Bolivarian farce around the continent. Although Hugo Chavez has funds for development worth $\$ 16$ billion and reserves worth $\$ 30$ billion, Venezuela's colossal import bill and domestic crisis will use up much of that (AP 2009) (Armas 2009 and O'Grady 2009). Hugo Chavez's budget is based on the presumption that the average cost of oil will be $\$ 90$ a barrel; the current price of Venezuela's thick crude is below $\$ 40$. Also good news is the fact that the populist model supported by the Argentine government, a tragicomic study in self-destruction, will be seen for what it really is. Finally, relations between the vegetarian (social-democratic) left and the carnivorous (revolutionary) left will be very strained, which will further isolate the radicals. Venezuela and Ecuador - two carnivores-recently declared political war on Brazil-a vegetarian-by refusing to pay their debts with the Brazilian development bank, a major source of funding for infrastructure projects in South America. Ecuador has backtracked somewhat but the tension is there.

Of course, in trying to anticipate the midterm effects of what is happening in the United States and elsewhere across the region one must always bear in mind that there is the possibility that the remedy that is being applied by the authorities in the United States to the credit crunch and the recession will either not work or even postpone the recovery. In that case, the consequences for Latin America as a whole would be a long period of stagnation perhaps followed by a rebirth of populism in countries such as Peru or Mexico where in recent elections the majority of voters seemed to clearly reject populist candidates. We have seen the left gain a lot of ground against the center-right government party in El Salvador in recent months already.

In my view, the response to the financial meltdown in the U.S. has been very risky. In the last three months alone, the United States' money supply has increased by an annual rate of 40 percent, if we don't count savings deposits. (It was 17 percent with savings deposits included.) That is half the rate of growth between 2001 and 2005, the period of easy money that created the conditions that led to the financial crunch in the first place. (Federal Reserve 2009). Since the Great Depression is the precedent most cited these days, we should remind 
ourselves that one of the most important causes of the crash of 1929 was the 61.8 percent increase in the money supply that took place between 1921 and 1929. (Rothbard 2000). Apart from the credit crunch, the U.S. faces a longer-term problem, as we all know. The net operating cost of the U.S. government for the last fiscal year (the net operating cost is considered by many a more accurate measure of the budget deficit) was $\$ 1$ trillion. You can imagine what these numbers will look like at the end of the current fiscal year once the economic stimulus package, probably worth close to $\$ 1$ trillion, is added.

The U.S. government's overall debt amounts to $\$ 10$ trillion - a bit less than half of it is related to Social Security and Medicare. In 2008, the cost of Medicare was already far in excess of the money generated by the tax that funds it; in 2017, when a second Obama administration would end, Social Security will be in the same situation. According to the Financial Report of the U.S. Government, which reads like a Stephen King novel, 15 years from now the debt will be higher, as a percentage of the nation's GDP, than at its worst period in American history. (US GAO 2009)

History teaches us that throwing money at financial panics or recessions can actually complicate the recovery. The danger for Latin America in this case is not just that the U.S. might generate inflation and postpone a total recovery but that the U.S. example might followed in many other countries. Unlike the U.S., a country that can afford to make monetary and fiscal mistakes, Latin America cannot. The region learned a very painful lesson in the 1980s, when the populist model based on inflation and fiscal irresponsibility generated what is known as the "lost decade."

Although much of what is happening originated outside of Latin America, we should point out that the region, which went through a boom of sorts in recent years, missed an opportunity to engage in profound reform. Rather than make the most of the boom years to eliminate obstacles to long-term growth, slash spending and put away some rainy-day money, Latin American governments preserved the status quo and boosted public expenditures by 10 percent annually in matters mostly unrelated to infrastructure, creating alarming new commitments. Except for Chile, which managed the revenue from its copper sales prudently, many of the nations that produce oil (Mexico, Venezuela, Ecuador), minerals (Brazil) or agricultural commodities (Argentina, Brazil, Uruguay) either went on a binge or in some cases, such as that of Peru, failed to reform the structure of public spending, most of which has nothing to do with investing in infrastructure. They will now find themselves starved for cash at a time when they are pledging new forms of government profligacy in the face of the global recession. The temptation to fund it via inflation will be strong.

It has been repeatedly said that Latin America has shifted to the left. What is actually happening is more complex than that. A cultural struggle is underway, cutting across political parties, social organizations and academic trends. It pits those who want to place Latin America in the global firmament and see it emerge as a major contributor to the Western culture to which its destiny has been attached for five centuries, and those who cannot reconcile themselves to the idea and do all they can to resist it.

The cultural tension between modernizers and reactionaries is holding back Latin America's development by comparison to other regions of the world - such as East Asia, the Iberian peninsula or Central Europe - that not long ago were examples of backwardness. Whenever the 
modernizers seem to get a breakthroughfor instance, the right or center-right in the 1990s - old habits prevent them from engaging in definitive reform, and when cultural reactionaries shed some of their dated ideas-as has happened with part of the left recently-they only go half way and end up preserving much of what needs to change.

The good economic performance of the past few years can easily make us lose sight of the fact that in the last three decades, every Latin American country except Chile has seen its per capita income fall as a proportion of U.S. income per head, whereas Thailand and Indonesia, two middleof the table Asian nations, have seen theirs rise by 40 percent. Latin America's performance cannot be compared with that of China or India. Only twelve years ago the size of Brazil's economy was similar to that of China. Today China produces three and a half times more goods and services than Brazil. (Heston 2006).

According to multilateral bodies, Latin America's annual GDP growth has averaged 2.8 percent in the last three decades-which compares unfavourably with Southeast Asia's 7.7 percent or the world average of 3.3 percent. Consequently, the region's income per capita has only risen from about $\$ 3,500$ in 1980 to about $\$ 7,000$ today (taking into account purchasing power parity). About 20 percent of the world's total stock of private capital is destined to the less developed countries. (IMF 2007). Although 2007 was an exceptionally good year in Latin America and we attracted more than $\$ 100$ billion in direct foreign investment as a region, in the last decade we have lagged far behind other underdeveloped regions in terms of attracting foreign capital. In Brazil, direct foreign investment has fallen from 5 percent to 2 percent of GDP since 2000. (World Bank 2009).
This sluggish performance explains why just under 40 percent of the population is still poor and why, after a quarter century of democratic rule, regional surveys betray a dissatisfaction with democratic institutions and traditional parties.

Three different types of governments and opposition movements can be seen in Latin America today: the center-right, the new left, and the old left. The division between the new left -what I and my two co-authors call in a recent book the "vegetarian" leftand the old left - what we call the "carnivorous" left-is perhaps the most important development of this decade. The struggle for the soul of the left between those who want to embrace globalization and those who oppose it will shape the political economy of the next few decades. The centerrightists and the vegetarian leftists are the modernizers in today's Latin America. The carnivore leftists are the reactionaries.

On the center-right, leaders such as Felipe Calderón (Mexico), Alvaro Uribe (Colombia) and Tony Saca (El Salvador) understand that the market economy and the rule of law are the foundations of prosperity. Except for some courageous reforms, the center-right has by and large chosen to preserve the legacy rather than substantially reform it. They have mostly maintained fiscal and monetary discipline and tried to lure foreign investors, but done little so far to transform the institutions, including the judiciary, and to incorporate the masses into the global economy by liberating them from bureaucratic constraints. Only Uribe has significantly reduced the high cost of starting new businesses. As a result of that reform, there has been a spectacular 35 percent rise in the number of new businesses in Colombia in the last four years .

It must also be said that, although the reforms have lost momentum in El Salvador, that country is somewhat of a model for 
Central America; thanks to courageous free-market reform undertaken by previous governments, especially the one headed by Francisco Flores, poverty has been reduced to about 35 percent in El Salvador. But this is not the rule among the center-right. The rule is stability rather than bold reform. Whether Felipe Calderón, Mexico's president, who is almost totally devoted to law and order issues right now and whose minority position in Congress will probably be confirmed in this year's legislative elections, will be able to deliver on his promises of free-market reform remains to be seen. We have seen the negative reaction in Congress to his timid attempts to open up the undercapitalized energy sector to private capital.

Then, there is the "vegetarian" left, represented by leaders such as Lula da Silva (Brazil), Alan García (Peru), Tabaré Vázquez (Uruguay), and Oscar Arias (Costa Rica), among others. Despite the occasional meaty rhetoric, these leaders have avoided the mistakes of the old left, including routine confrontation with the outside world and monetary and fiscal profligacy. But they have settled into a sort of social-democratic placidity, and are proving unwilling to rattle the cage too much. Their success, as in the case of Lula and García, is due to sound management rather than reform of the government. They maintain healthy macroeconomic indicators (although that will now change because of the U.S. and international crisis) and, in some cases, have resisted pressure from their base to go back to old-style populism, but they are not necessarily reducing the bureaucracy and taxation, or strengthening the rule of law as much as they should. Before the current crisis, Brazil's GDP growth did not quite reach 5 percent in 2008 despite receiving $\$ 34$ billion in foreign direct investment the previous year, twice more than the previous year. It was not bad, but it could have been better. (IMF 2009).

Then there is the "carnivorous" left, represented by Fidel Castro, Hugo Chávez, Nicaragua's Daniel Ortega, Bolivia's Evo Morales, and Ecuador's Rafael Correa (and Paraguay's Fernando Lugo is knocking at the door.) They cling to a Marxist view of society and a Cold-War mentality that separates the North from South, and seek to exploit ethnic tensions, particularly in the Andean region. The oil windfall obtained by Hugo Chávez was funding a great deal of this effort until the drop in oil prices hit Venezuela. According to various sources, his subversive petro-diplomacy has so far cost dozens of billions that do not belong to him but to the Venezuelan people. As we have seen, that funding may dry out soon.

The gastronomy of the Kirchner couple in Argentina is ambiguous-they are situated somewhere between the carnivores and the vegetarians, although Cristina Kirchner's government has moved close to the carnivores in recent months. Taking into account the current and the previous government, the couple have inflated the currency, established price controls on half the products that make up the consumer price index, and either nationalized or created government-owned enterprises in the major sectors of the economy. But they have avoided revolutionary extremes and even paid the debt to the International Monetary Fund. That is changing, however, as the crisis pushes the couple towards radicalization. The recent takeover of the private pension system, which accounts for the bulk of the country's savings, in order to meet debt obligations and maintain the apparatus based on political patronage $s$ a disturbing sign. Now that the agricultural sector, where the Kirchners obtained most of the revenue from, is hurting in the face of the drop in international demand, it is quite conceivable that they will go further down the path of radical populism. Cristina Kirchner's trip to Cuba a few days ago perhaps signals just that. 
The differences among the left are as big as they are between the left and the right. Both carnivores and vegetarians blocked the Free Trade Area of the Americas that the U.S. and 29 Latin American nations wanted to sign. But South American integration - which was presented as the alternative to hemisphere-wide integration-is a patchwork of competing sub-regional blocs riddled with internal fighting from which nothing consistent has emerged despite the Bolivarian rhetoric. It is hard to understand why the 29 nations did not go ahead and leave MERCOSUR behind since the combined world trade of MERCOSUR countries (including their new member, Venezuela) amounts to a meager 7 percent of the total world trade of all the other nations in this hemisphere if we include United States and Canada.

In recent years, the combination of economic growth thanks to an economy that is more open than it was in the 1980s has helped generate a new low middle-class in our countries. The sale of cars, computers and consumer electronics in countries like Brazil and Mexico has reached record numbers. Unlike the middle class that emerged in the 1940s-1970s period, which was related to economic nationalism (bureaucrats, managers, labor unionists), the new middle class is linked to the market - partly to small businesses that serve consumers or provide services to bigger corporations. According to Banco Santander, 15 million households ceased to be poor and became low middle-class between 2002 and 2006 (El País 2007). In Mexico, the number of families with monthly incomes of between $\$ 600$ and $\$ 1,000$ rose from 5.7 million in 1996 to 10.7 million in 2006. In Argentina, the proportion of families making $\$ 1,000$ a month rose from 20 percent in 2003 to 40 percent in 2006.

Apart from the emergence of a new low middle class, there has been some pover- ty relief in Latin America because extraordinary international conditions brought in some revenue that governments like Brazil, Mexico, and Colombia devoted to cash stipends among the extremely poor in exchange for sending their kids to school. Millions of Latin Americans have enrolled in those programs -44 million in Brazil alone (World Bank 2005). Now that conditions have worsened dramatically, if will be impossible to sustain these subsidies.

Because of the absence of major reforms since the end of the 1990s, investment levels are still low in Latin America compared to over 25 percent in the exceptional case of Chile and close to 30 percent in other developing areas. The standard of living is not rising in a very substantial way for the majority of people. In any event, reducing poverty through handouts brings alleviation to poor countries, but it does not amount to sustained, long-term capital accumulation of the kind that, according to the World Bank, has brought almost 400 million people out of poverty in the last two decades around the world thanks to free-market reforms. Between 2003 and 2005, Latin America's economy grew by 53 percent but productivity grew less than 4 percent, according to "Can Latin America Compete", a recent book by Jerry Haar and John Price. (Haar 2008: p. 1).

All this means that Latin America needs to make a much bigger effort to be competitive. The cost of not being competitive enough over the last 15 years, measured by the net flight of capital and brain power, is estimated to have been $\$ 1.3$ trillion, and it continues to cost the region $\$ 160$ billion a year. (Haar 2008: p. 7).

What is missing in Latin America is the torrent of entrepreneurial activity that other regions of the world were able to unleash through institutional reform. Winston Churchill wrote, "Some people regard private 
enterprise as a predatory tiger to be shot. Others look on it as a cow they can milk. Not enough people see it as a healthy horse, pulling a sturdy wagon." Of the world's one hundred largest economies, 51 are private corporations. While the significance of private enterprise is obvious, in Latin America we have been wary of private enterprise. Our system has not been very conducive to entrepreneurship. We have too many obstacles to private enterprise, there are too many state-owned companies in key sectors, taxation is too heavy, our labor laws are too rigid, there is little incentive for innovation and perhaps more importantly, in some countries the systems of justice are not very reliable.

It still costs more to open a business in Latin America than anywhere except the Middle East and Africa. Only part of the Latin American economy is fully global.

In many Latin American nations, there is still scant connection between academic research centers and the productive economy, part of the reason why, with the exception of Mexico and Brazil, those economies-including Chile's-are overwhelmingly dependent on natural resources and commodities. Even Brazil's economy depends on natural resources or commodities for one third of its exports. In Peru, they represent two thirds of the nation's exports. The four largest firms in Latin America are government monopolies or quasi monopolies involved in oil exploitation and refining (América Economía 2008). What an irony that the very same left that a few years ago decried the region's dependence on raw materials and accused rich countries of maintaining "unjust terms of trade" with Latin America whereby we sold them cheap commodities and they sold us expensive industrial and capital goods are now enjoying an orgy of commodity dependence. Apart from cheap tourism, Argentina has been mostly living off the sales of its commodities.

Governments think that "strategic sectors" need to be in inefficient and corrupt state hands. Oil generates 40 percent of the Mexican government's revenue. The impediments to private investment are reducing oil production. Mexico's Cantarell project, representing two thirds of oil production, will lose half of its output capacity in the next couple of years because of undercapitalization (Vargas LLosa 2007). The high cost of energy and taxes needed to sustain this hurts the country's competitiveness. Electricity is also in government hands in Mexico. At the other end of Latin America, we have the case of Bolivia, which has not exploited its 52 TCF of natural gas reserves fully because of political agitation regarding foreign investment (foreign investors actually discovered the reserves in the 1990s.)

There are too many taxes and the tax code is labyrinthine. Some Brazilian companies pay 61 different taxes that eat up 70 percent of the profits (Margolis 2005). There are too many brackets and differentiated regimes-especially on consumption, limiting production, investments and savings. These distortions increase transaction costs. Mexican small and medium-sized companies spend 30 percent of their resources hiring squadrons of tax and accounting specialists. It costs too much to hire and fire workers. In many African countries, employers don't incur any costs other than wages when hiring a worker.

There are too many restrictions on wage bargaining and labor mobility, including impediments to the free contracting of workers outside of unions. There is little linkage between wage remuneration and productivity.

Another factor that hinders our ability to compete better is the lack of sufficient innova- 
tion. Brazil, for instance, has created some clusters of innovation in the form of "tech parks" but they are in the early stages. And it is true that Brazilians have made breakthroughs in bio-energy, including ethanol fuel and bio-diesel, agricultural and tropical forest management, and deep-sea petroleum geology. It is also true that Argentina has a software cluster in Córdoba thanks to government-created incentives, or that, in Costa Rica, a number of engineering schools are linked to Intel. But these efforts are partial, isolated and heavily dependent on government funds.

In Jalisco, Mexico, some companies (Hewlett-Packard, IBM, Intel, Siemens VDO) are working with universities on innovation projects. However, a study by the pharmaceutical company Merck says that Mexico is good at coming up with new ideas and selling the final product but not at transferring the technology from the research center to the company and commercializing it. The government forces the local pharmaceutical industry to sell cheaply to the state toward Social Security, so most companies cannot invest in Research Development. Only 0.4 percent of the country's GDP is invested in R\&D. (Council on Competitiveness 2005).

Contracts are very poorly enforced and the absence of judicial reform affects our region's ability to fight poverty. It means, for instance, that even with property title reform the economic benefits are small. More than 1.2 million property titles were distributed to urban squatters by the Peruvian government in the last 15 years (Field 2006). But the banks have not been willing to lend those title holders money: they just don't trust their own ability to foreclose because they don't trust the courts or because they perceive that there is political interference (the government will protect poor families that default on private bank loans.)
All of this needs to change fundamentally. We have the entrepreneurial potential. What we need to do is set free the people's creative powers.

We know that prosperity is the reward of systems that protect property rights. But some of our governments have acted a little bit like mafias, protecting some individual rights in exchange for a share of the rent while abrogating in practice the rights of others. The result has been little entrepreneurial activity, low productivity and insufficient capital accumulation. When Latin Americans institutions finally decide to protect everybody's property rights, those nations will find lasting prosperity. Not a day earlier. 


\section{References}

Alves, Fabio. (2008). "Brazilian Stocks Cap Worst Year Ever After Commodities Plunge", Bloomberg. December 30. (http://www.bloomberg.com/apps/news?pid=conewsstory E'refer=conews E'tkr $=B N C A 3 \% 3 A B Z$ Esid=a8I.8ImkV7gk).

América Economía. (2008). "Las 55 mayores empresas de América Latina", América Economía. October 27. (http://beta. americaeconomia.com/110442-Las-500-mayores-empresas-de-america-latina.note.asp $x$ )

AP. (2009). "Tapping Reserves Risky For Venezuela", International Herald Tribune. January 18. (http://www.ibt.com/ articles/ap/2009/01/18/business/LT-Venezuela-Foreign-Reserves.php)

Armas, Mayela. (2009). "National Development Fund Has USD 16 Billion Available", El Universal. January 29. (bttp://english.eluniversal.com/2009/01/29/en_eco_art_national-development_29A2209709.shtml)

Council on Competitiveness. (2005). Catalizing Cross-Border Innovation: The Mexican Life Sciences Initiative (Phase I), a report by the Council on Competitiveness. December.

El País. (2007). "Una clase que surge a medias", El País Digital. September 2. (bttp://www.elpais.com.uy/Suple/ DS/07/09/02/sds_300661.asp)

Federal Reserve. (2009). Statistics and Historical Data, Board Of Governors of the Federal Reserve System. February 2009. (http://www.federalreserve.gov/econresdata/releases/statisticsdata.htm)

Field, Erica and Maximo Torero (2006). Do Property Titles Increase Credit Access Among the Urban Poor? Evidence from a Nationwide Titling Program. March.

(http://www.economics.harvard.edu/faculty/field/papers/FieldTorerocs.pdf.)

Haar, Jerry and John Price. (2008). "Can Latin America Compete", in Can Latin America Compete? Confronting the Challenges of Globalization. New York: Pallgrave Macmillan.

Heston, Alan, Robert Summers and Aten, Bettina. (2006). Penn World Table Version 6.2. Center for International Comparisons of Production, Income, and Prices at the University of Pennsylvania. September.

(http://datacentre2.chass.utoronto.ca/pwt/)

IMF. (2009). World Economic Outlook Update, International Monetary Fund. January 28.

(bttp://www.imf.org/external/pubs/ft/weo/2009/update/01/pdf/0109.pdf)

IMF. (2007). World Economic Outlook Update, International Monetary Fund, January 28.

(http://www.imf.org/external/pubs/ft/weo/2007/update/01/pdf/0109.pdf)

Kraul, Chris. (2008). "Brazil Unfazed by the US Market Crisis", The Los Angeles Times. September 22. (bttp://articles.latimes.com/2008/sep/22/world/fg-brazil22)

Loser, Claudio. (2008). "Possible Costs to the Region of the World Financial Crisis", Inter-American Dialogue's Latin America Advisor. December 4. (http://www.thedialogue.org/page.cfm?pageID=32\&pubID=1706 \&ss=)

Margolis, Mac. (2005). "Time to Say Enough? Brazilians Pay 61 Different Taxes", Newsweek International. March. (http://www.accessmylibrary.com/coms2/summary_0286-191he Wall91492_ITM) 
Merle, Renae. (2009). “Wall Street's Final 08 Toll: \$6.9 Trillion Wiped Out”, The Washington Post. January 1. (http://www.washingtonpost.com/wp-dyn/content/article/2008/12/31/AR2008123101083.html)

O’Grady, Mary. (2009). “Chávez Grabs Again for Life Tenure”, The Wall Street Journal. February 2.

Ratliff, William. (2008). China's Latin America Tango", The Wall Street Journal. November 26. (http://online.wsj.com/article/SB122772793674260489.html)

Rothbard, Murray. (2000). America's Great Depression, 5th ed.. Auburn: AL: Ludwig Von Mises Institute. P. 4, 6-7, 9, 12, 14, 92-93, 95.

US GAO. (2009). Fiscal Year 2008 Financial Report of the United States Government, U.S. Government Accountability Office. (http://www.gao.gov/financial/fy2008financialreport.html)

Vargas Llosa, Alvaro. (2007). "The Return of the Idiot”, Foreign Policy Magazine. May/June.

(bttp://www.foreignpolicy.com/story/cms.php?story_id=3805 छppage=2)

Word Bank. (2009). Key Development Data E' Statistics, The World Bank. 2009. (http://web.worldbank.org/WBSITE/ EXTERNAL/DATASTATISTICS/O, contentMDK:20535285 menuPK:1192694 pagePK:64133150 piPK:64133 175 theSitePK:239419,00. html)

World Bank. (2005). Lifting Families Out of Poverty in Brazil-Bolsa Familia Program. December. (http://web.worldbank.org/WBSITE/EXTERNAL/COUNTRIES/LACEXT/BRAZILEXTN/0,contentMDK:20754490 pagePK:1 41137 piPK:141127 theSitePK:322341,00.html) 